\title{
Expression of the C-terminal flanking peptide of human progastrin in human gastroduodenal mucosa, G-cell hyperplasia and islet cell tumours producing gastrin
}

\author{
M. Hara, I. M. Varndell, A. E. Bishop, M. Aitchison, ${ }^{*}$ J. Rode, $\dagger$ \\ T. Yamada, \$ D. M. Green, $\S$ S. R. Bloom and J. M. Polak \\ Departments of Histochemistry and Medicine, Royal Postgraduate Medical \\ School, Hammersmith Hospital, Du Cane Road, London W12 OHS, UK, \\ *Department of Surgery, Inverclyde Royal Hospital, Greenock, Scotland, UK, \\ ${ }^{\dagger}$ Bland-Sutton Institute of Pathology, The Middlesex Hospital Medical School, \\ London W7P 7PN, UK, 'Department of Internal Medicine, The University of \\ Michigan Medical Center, Ann Arbor, Michigan 48109, USA, and \\ ${ }^{\S}$ Department of Pathology, University of Leeds, Leeds LS2 9/T, UK
}

(Received 18 November 1986, Accepted 21 January 1987)

\begin{abstract}
Three antisera to the C-terminally extended form of gastrin or the C-terminal flanking peptide of progastrin were used in an attempt to investigate the post-translational processing of progastrin at the cellular level by light and electron microscopical immunocytochemistry.

In the normal human gastric antrum, the G-cell secretory granules were found to contain both gastrin and the $\mathrm{C}$-terminal progastrin determinants (progastrin 87-93, 87-95 and 93-101). Immunostaining of serial sections at the light microscopical level revealed that duodenal gastrin-containing cells also express the C-terminal progastrin determinants, as well as gastrin-34. In foetal tissue, cells containing C-terminal gastrin and the Cflanking peptide of progastrin were first seen at 8 weeks of gestation, in the duodenum. They were not found in the stomach until the 11th week. In hyperplastic $\mathrm{G}$-cells and in gastrin-producing tumour cells, the level of C-terminal peptide immunoreactivity was variable and often lower than that seen in normal antrum and only minimal immunoreactivity could be detected using electron immunocytochemistry. This was interpreted as representing altered post-translational processing of progastrin in modified G-cells.
\end{abstract}

KEYWORDS: Gastrin, C-terminal peptide of progastrin, immunocytochemistry, electron microscopy, G-cell hyperplasia, gastrin-producing tumours.

Address for all correspondence: Professor J. M. Polak, Department of Histochemistry, Royal Postgraduate Medical School, Hammersmith Hospital, Du Cane Road, London W12 OHS, UK. 


\section{INTRODUCTION}

Most, if not all, bioactive peptides are derived from larger precursor molecules (prohormones) by proteolytic cleavage at sites characterized by the presence of dibasic amino acid residues. ${ }^{\top}$ Indeed, many prohormones have been found to contain multiple peptide sequences, limited by potential cleavage sites, a number of which may effect a biological function, for example pro-opiomelanocortin (POMC) contains the sequences of $\mathrm{ACTH}$, endorphin, $\beta \mathrm{LPH}, \mathrm{MSH}$ and CLIP ${ }^{2}$ and proglucagon those of glucagon, glucagon-related pancreatic peptide, glicentin, glucagon-like peptides 1 and $2 .^{3-5}$ As the post-transiational enzymatic cleavage of the prohormones may be activated differentially by tissue-specific mediators, it is necessary to determine which sequences are elaborated by each prohormonecontaining endocrine cell type.

Endocrine cells typically contain secretory granules with varied morphology which is thought to reflect storage of different molecular forms of bioactive peptides produced during post-translational processing. The mammalian G-cell has been shown to contain two main granule populations. ${ }^{6-8}$ We have previously investigated the processing of gastrin in human G-cells and shown that these two populations, in fact, correspond to the extremes of the granular maturation process. ${ }^{9}$ Immature, small electron-dense granules contain both G17 and G34 whilst the intermediate forms of pale-cored granules have G17 alone. The large, electron-lucent granules show little or no gastrin immunoreactivity.

More recently, the structure of progastrin has been deduced from the nucleotide sequence of mRNA cloned from porcine gastric antrum, ${ }^{10}$ human gastric antrum ${ }^{11}$ and human pancreatic gastrin-producing tumours (Zollinger-Ellison syndrome). ${ }^{12}$ Human progastrin consists of 101 amino acids, within which is a single copy of gastrin-34 ('big gastrin', G34; Fig. 1). ${ }^{12}$ A nine amino acid sequence (-Gly-Arg-Arg-SerAla-Glu-Asp-Glu-Asn) flanks G34 at the C-terminal of the precursor. We have used antisera raised against three synthetic regions of this flanking peptide (see Table 1) in an immunocytochemical study in order to determine the intracellular localization of the C-terminal peptide in normal human stomach and duodenum (developing and adult), stomach with G-cell hyperplasia and in pancreatic tumours producing gastrin.

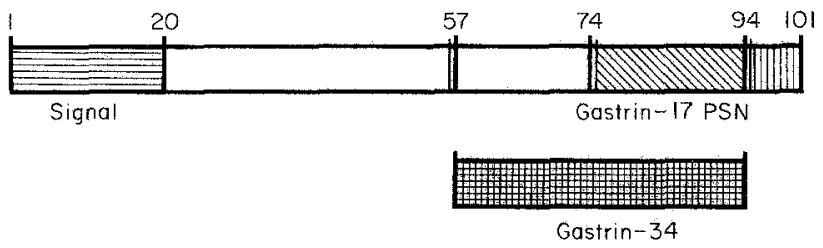

Fig. 1. Diagram of the human progastrin molecule showing the positions of G34, G17 and PSN. 
Expression of human progastrin

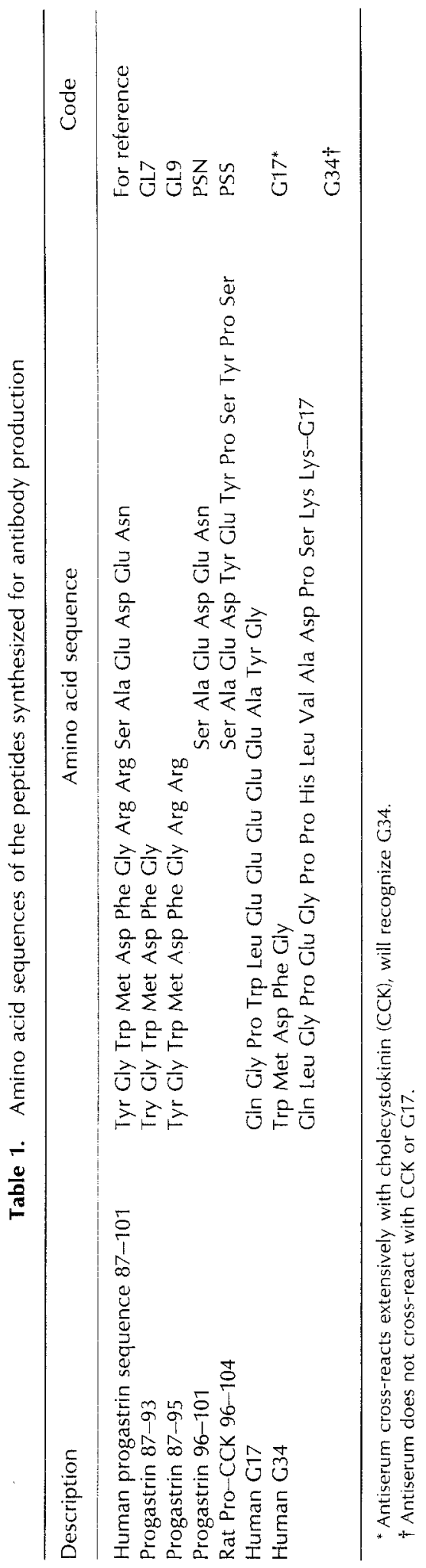




\section{MATERIALS AND METHODS}

\section{Tissues}

Specimens of gastric antrum $(n=3)$, duodenum $(n=5)$ and pancreatic islet cell tumours producing gastrin $(n=6)$ were obtained at surgery. Endoscopic biopsy specimens of gastric antrum from patients with pernicious anaemia $(n=10)$ were obtained by endoscopy. The stomachs from 25 foetuses (8-28 weeks' gestation) were collected at legal terminations of pregnancy or from spontaneous abortions.

\section{Light microscopy}

Tissues were fixed in Bouin's solution or $10 \%$ neutral-buffered formalin, embedded in paraffin wax and sectioned at $5 \mu \mathrm{m}$. For co-localization studies some fixed tissue was embedded in epoxy resin (see Electron microscopy below) and serially sectioned at $0 \cdot 5-1 \cdot 0 \mu \mathrm{m}$.

\section{Light microscopical immunocytochemistry}

Immunocytochemical studies were performed using the peroxidase anti-peroxidase (PAP) technique. ${ }^{13}$ Sections were de-waxed in inhibisol or de-resinated in sodium alkoxide $^{14}$ and brought to phosphate-buffered saline (PBS, $\mathrm{pH} 7 \cdot 2$ ).

Endogenous peroxidatic activity and non-specific staining were blocked by incubation for $30 \mathrm{~min}$ in $0.3 \%$ hydrogen peroxide in PBS followed by a further $10 \mathrm{~min}$ in normal goat serum (1:30 dilution in PBS).

The primary antisera were applied for $16-24 \mathrm{~h}$ at $4^{\circ} \mathrm{C}$ in a moist atmosphere. Full details of the primary antisera are given in Tables 1 and 2. After thorough rinsing in PBS, a second layer, goat anti-rabbit IgG antiserum (Miles Labs, Stoke Poges, UK) was applied for $30 \mathrm{~min}$ at 1:200. Following further rinses in PBS, the sections were incubated with rabbit PAP complex (Miles Labs) for $30 \mathrm{~min}$ at 1:400 dilution. Localization of the PAP complex was achieved using a solution of 3,3'-diaminobenzidine tetrahydrochloride $(0.025 \%)$ and hydrogen peroxide $0.01 \%$ in PBS for $5-$ $8 \mathrm{~min}$. After development of the reaction product the sections were dehydrated through graded ethanols to xylene, mounted in DPX and examined with a transmitted light microscope.

\section{Electron microscopy}

Specimens of each tissue were fixed in 2.5-3.0\% glutaraldehyde in $0.1 \mathrm{M}$ sodium phosphate buffer $\mathrm{pH} 7.2$ for $2-4 \mathrm{~h}$. After rinsing in $0.1 \mathrm{M}$ sodium phosphate buffer $\mathrm{pH} 7 \cdot 2$ containing $0.1 \mathrm{M}$ sucrose half of the blocks were osmicated $(1 \%$ osmium tetroxide in Millonig's phosphate buffer, $\mathrm{pH} 7 \cdot 2$ for $1 \mathrm{~h}$ ). The samples were then rinsed in buffer, dehydrated through a graded series of ethanols and embedded in Araldite epoxy resin. Ultra-thin sections, showing silver to silver-grey interference colours, were mounted on cleaned, uncoated 200- or 300-mesh hexagonal nickel grids. 
Table 2. Dilutions of the antisera used

\begin{tabular}{lcc}
\hline & \multicolumn{2}{c}{ Dilutions* $^{*}$} \\
Code & PAP & IGS \\
\hline GL7 & $1: 1600$ & NS \\
GL9 & $1: 800$ & NS \\
PSN & $1: 1000$ & $1: 5000$ \\
PSS & $1: 500$ & $1: 2000$ \\
G17 & $1: 5000$ & $1: 2500$ \\
G34 & $1: 1600$ & $1: 1000$ \\
\hline *PAP, light microscopical peroxidase & anti-peroxidase \\
method; iCS, immunogiobulin-gold staining method (electron \\
microscopy); NS, antisera not suitable for ultrastructural locali- \\
zation.
\end{tabular}

\section{Electron microscopical immunocytochemistry}

A modified immunoglobulin-gold staining procedure was used. ${ }^{15,16}$ Briefly, sections of osmicated tissue were treated with a saturated aqueous solution of sodium metaperiodate for $3060 \mathrm{~min}^{17}$ to diminish the protein masking effect of osmium. After rinsing in PBS the grids were incubated in normal goat serum at $1: 20$ dilution in PBS for $30 \mathrm{~min}$ followed by primary antiserum for $2-3 \mathrm{~h}$ at room temperature, or overnight at $4^{\circ} \mathrm{C}$ at optimal titre (Table 2). The grids were thoroughly washed on droplets of $50 \mathrm{mmol}$ Tris- $\mathrm{HCl}$ buffer, $\mathrm{pH} 7 \cdot 2$, containing $0 \cdot 1 \%$ Tween $20(3 \times 5 \mathrm{~min})$, $50 \mathrm{mmol}$ Tris- $\mathrm{HCl}$ buffer, $\mathrm{pH} 7 \cdot 2$, containing $0.1 \%$ Tween 20 and $0.2 \%$ bovine serum albumin (BSA, Sigma fraction V, globulin-free; $2 \times 5 \mathrm{~min}$ ) and $50 \mathrm{mmol}$ Tris- $\mathrm{HCl}$ buffer, pH 8.4, containing $0.1 \%$ Tween 20 and $1 \%$ BSA $(1 \times 5 \mathrm{~min})$. This washing step was followed by incubation in $10 \mathrm{~nm}$ gold-labelled goat anti-rabbit IgC (Janssen Pharmaceutica, Beerse, Belgium) at optimal titre for 30-60 min. Excess gold-labelled reagents were washed off with $50 \mathrm{mmol}$ Tris- $\mathrm{HCl}$ buffer, $\mathrm{pH} 7 \cdot 2$, containing $0 \cdot 1 \%$ Tween $20(6 \times 3 \mathrm{~min})$ followed by distilled water $(3 \times 3 \mathrm{~min})$. The grids were then counterstained with methanolic uranyl acetate and aqueous lead citrate before viewing in a transmission electron microscope.

Specificity controls were performed as in Table 3.

Table 3. PSN antiserum absorption test

\begin{tabular}{llccc}
\hline \multirow{2}{*}{$\begin{array}{l}\text { Peptide } \\
\text { concentration }\end{array}$} & \multicolumn{4}{c}{ Peptide used for absorption } \\
\cline { 2 - 5 } $20 \mathrm{nmol} \mathrm{ml}^{-1 *}$ & $\begin{array}{c}\text { Completely } \\
\text { absorbed } \\
\text { Completely } \\
\text { absorbed }\end{array}$ & Not absorbed & Not absorbed & NT \\
$10 \mathrm{nmol} \mathrm{ml}^{-1}$ & Nartially absorbed & NT & NT & Not absorbed \\
$1 \mathrm{nmol} \mathrm{ml}^{-1}$ & $\begin{array}{c}\text { Not absorbed } \\
0.1 \mathrm{nmol} \mathrm{ml}^{-1}\end{array}$ & NT & NT & NT \\
$0.01 \mathrm{nmol} \mathrm{ml}^{-1}$ & Not absorbed & NT & NT & NT \\
\hline
\end{tabular}




\section{RESULTS}

In this paper, for clarity, each antiserum is referred to by its code, i.e., antiserum PSN was raised against the $C$-terminal flanking nonapeptide of progastrin (progastrin 93101; see Table 1 and Fig. 1); CL7 against a C-terminal heptapeptide (progastrin 8793); GL9 against a C-terminal nonapeptide (progastrin 87-95). Antiserum PSS was raised against the $C$-terminal flanking peptide (96-104, see Table 1) of procholecystokinin (PSS). However, such a description is not meant to reflect an absolute specificity for that particular antiserum, but simply to designate the antigen used in immunization.

The results of the antiserum adsorption tests are given in Table 3. Immunostaining with an antiserum to the C-terminal flanking peptide of progastrin (PSN) could be prevented completely by pre-adsorption with $10 \mathrm{nmol}$ of homologous peptide $\mathrm{ml}^{-1}$ diluted antiserum, whereas the same antiserum was unaffected by $10 \mathrm{nmol} \mathrm{ml}^{-1}$ of the C-terminal flanking peptide of procholecystokinin (PSS) and $20 \mathrm{nmol} \mathrm{ml}^{-1}$ of PSN-tyrosine and gastrin-17. The specificities of antisera GL7 and GL9 are reported elsewhere. $^{18}$

Many cells reactive to antisera raised against C-terminal immunoreactants of human progastrin (PSN, GL7 and GL9) were found in the human gastric antrum (Fig. 2). These cells showed a similar distribution and number to the cells identified by antisera to gastrin-17 and gastrin-34. However, the immunostaining was localized predominantly to the perinuclear region of the $\mathrm{G}$-cells, though it was not restricted to it. Antisera PSN and gastrin-17 were found to detect reactive material in the same (G) cells on semi-thin serial resin sections (Fig. 3). Hyperplastic G-cells also showed immunoreactivity to antisera PSN, GL7, GL9 and gastrin-34, but the density of immunostaining was more than that in normal G-cells (Fig. 4). At the ultrastructural level in the normal antrum, gastrin-17 antiserum was found to react with both immature (small [160-220 nm] spherical, electron-dense) and mature (large [240$320 \mathrm{nml}$, spherical, pale-cored) secretory granules (Fig. 5), as previously described. ${ }^{9}$ Similar results were obtained with antiserum PSN. However, in the highly active, hyperplastic G-cells only minimal immunoreactivity to antiserum PSN was observed.

In the duodenum, a few cells immunoreactive with the PSN, GL7 and GL9 antisera were observed. These cells showed a similar number and distribution to those demonstrated by the gastrin-34 antiserum; however, this finding was in distinct contrast to the large number of cells identified using the antiserum to gastrin-17, some of which probably correspond to cholecystokinin-containing cells.

In foetal tissue, cells containing the C-flanking peptide of progastrin and Cterminal gastrin were present in the duodenum from 8 weeks' gestation onwards (Fig. 6). However, these cells were not seen in the stomach until 11 weeks of gestation (Fig. 7). Immunostaining on serial sections demonstrated that C-terminal gastrin (gastrin-17)-immunoreactive cells also contained PSN immunoreactivity at all stages of development. However, in later foetuses (20-28 weeks) gastrin-17immunoreactive cells were seen more frequently than those immunostained with the antiserum to PSN.

In the islet cell tumours producing gastrin, antisera PSN, GL7, GL9, gastrin-17 and gastrin-34 revealed a similar, though variable, pattern of localization. In some cases scattered cells were stained, in others solid blocks of tumour cells (Fig. 8, Fig. 4). As in 

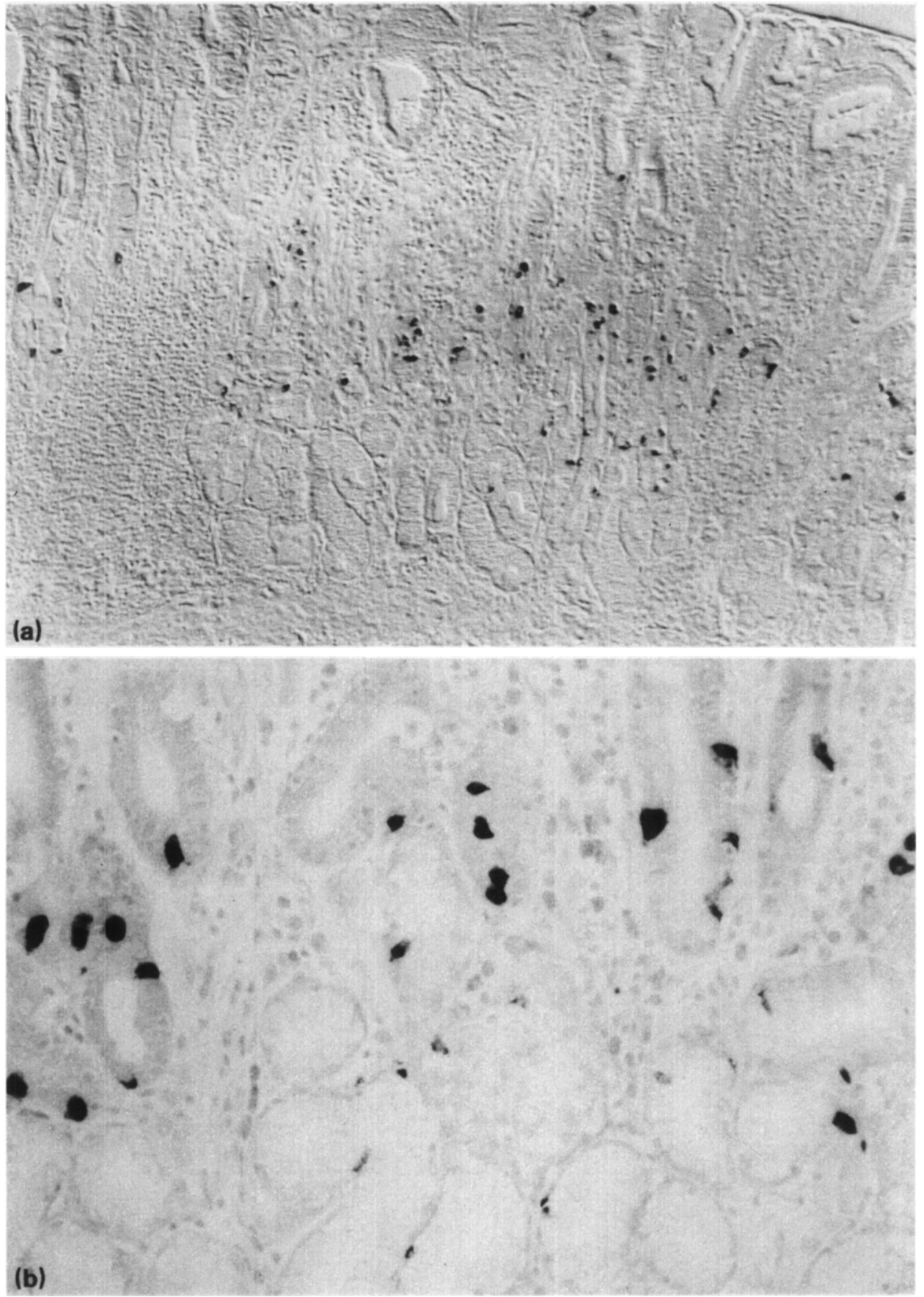

Fig. 2. Human antral mucosa containing scattered cells showing immunoreactivity for PSN. (a) Low magnification $(\times 50)$ (with Nomarski optics). (b) Higher magnification $(\times 200)$. 
M. Hara et al.
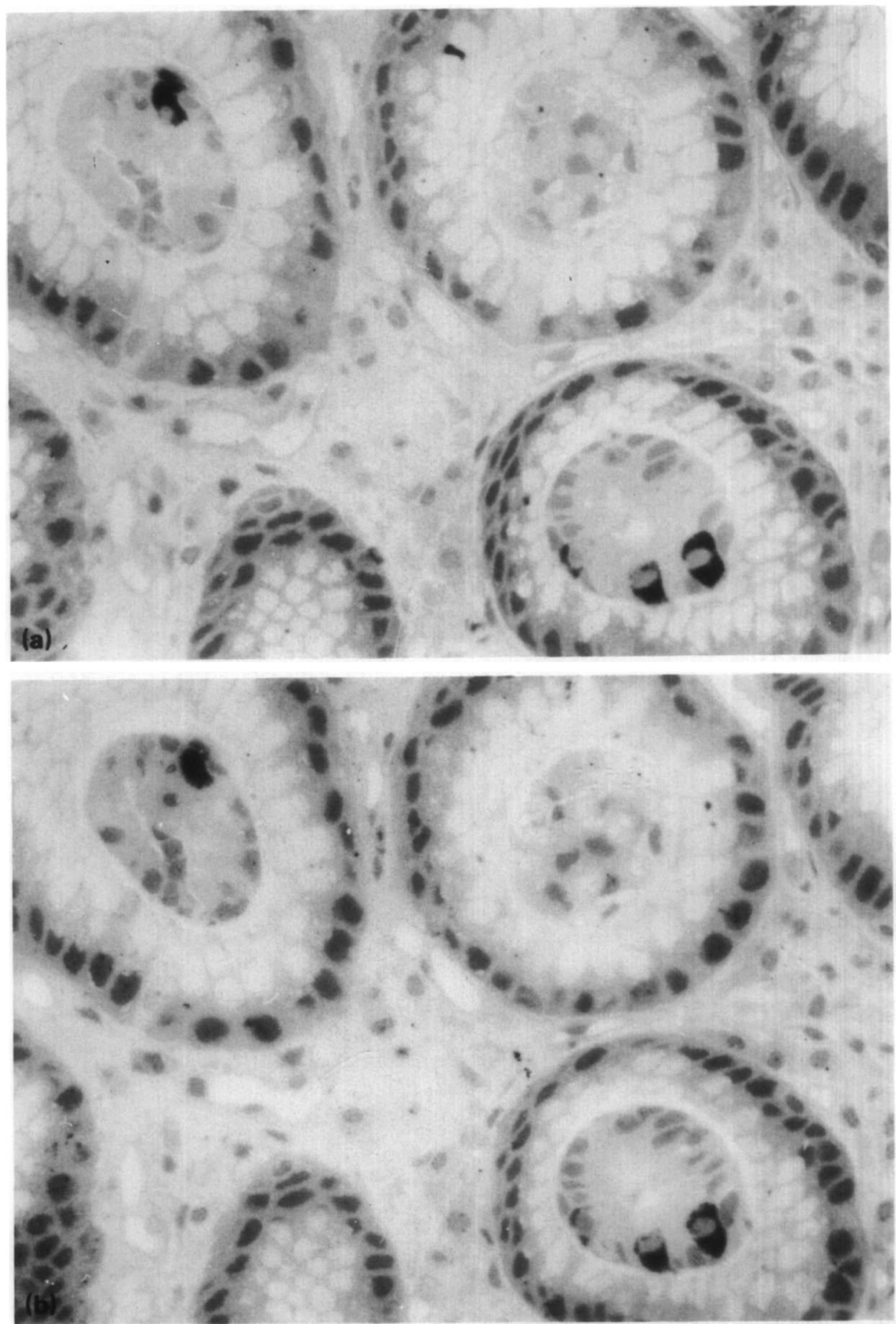

Fig. 3. Serial semi-thin sections of resin-embedded human antrum immunostained with antisera (a) G17, (b) PSN. The same cells can be seen in both sections and showing immunoreactivity for the two portions of progastrin. Magnification $\times 300$. 

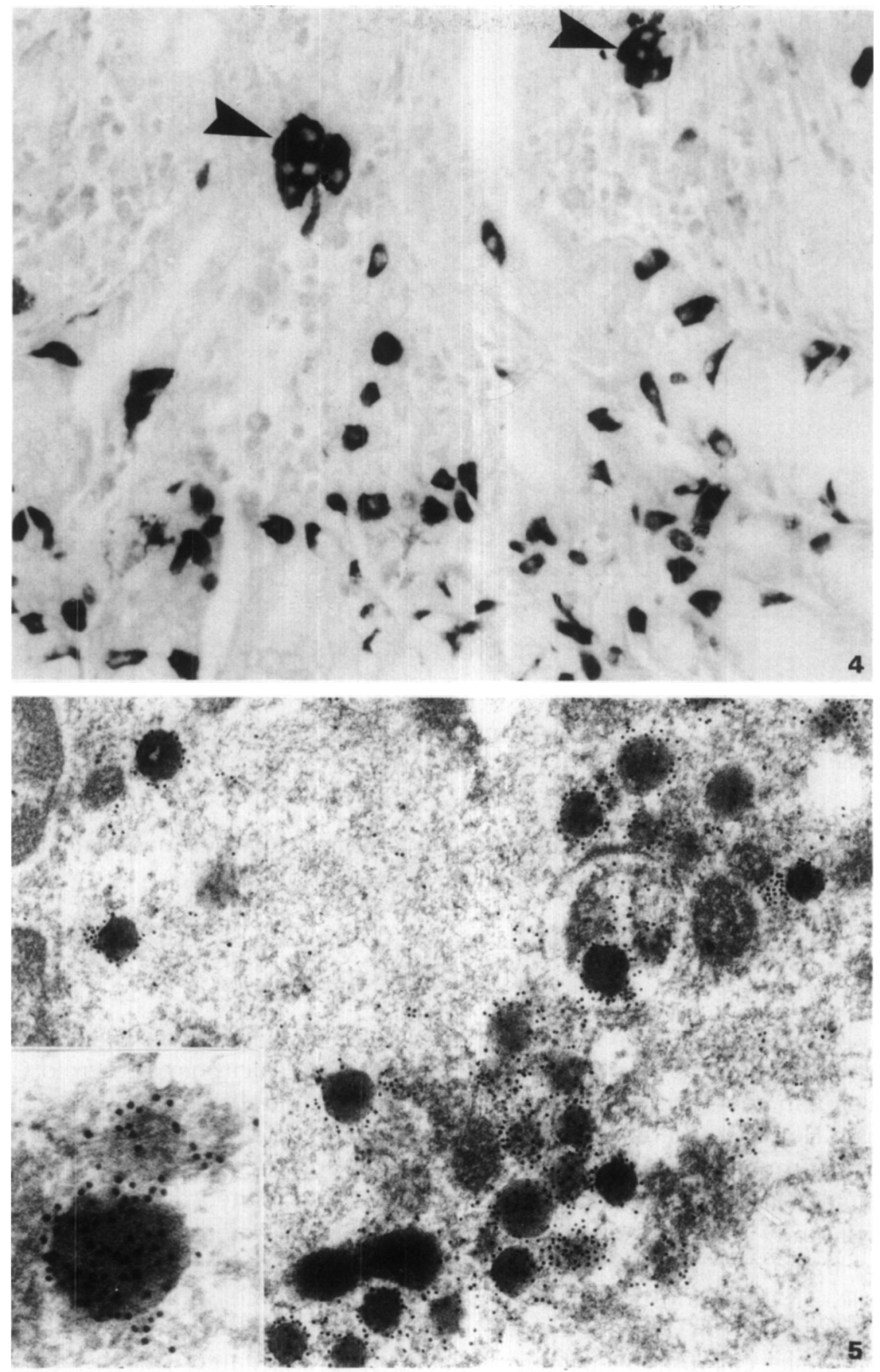

Fig. 4. Antral mucosa from a patient with pernicious anaemia showing large numbers of PSN-irmmunoreactive cells, some of which occur in abnormal clumps (arrows). Magnification $\times 170$.

Fig. 5. Electron micrograph of PSN immunoreactivity in a normal G-cell from human gastric antrum. Immuno-gold staining method using $10 \mathrm{~nm}$ gold particles. The tissue is non-osmicated. Magnification $\times 80,000$ and (inset) $\times 200,000$. 


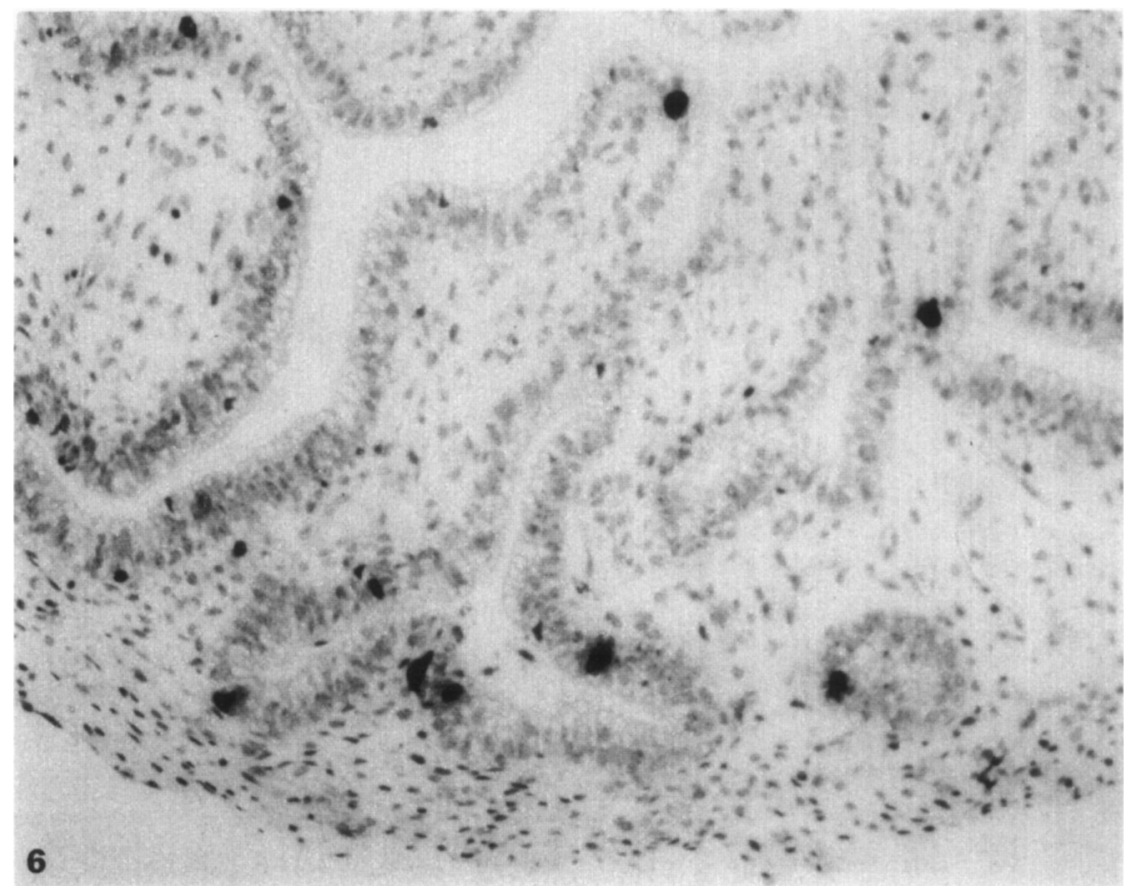

Fig. 6. Cells showing immunoreactivity for antiserum PSN in human duodenum at 8 weeks' gestation. Magnification $\times 250$.

the hyperplastic G-cells, at the electron microscopical level, minimal immunoreactivity to antiserum PSN was obtained in G-cell tumours.

\section{DISCUSSION}

Alternative processing of genomic DNA nucleotide sequences can result in tissuespecific expression of primary transcripts, for example calcitonin in thyroid C-cells and calcitonin gene-related peptide (CCRP) in both central and peripheral nervous systems. ${ }^{19}$ However, there are many instances of multiple peptide sequences from single prohormones being expressed, synthesized and secreted by the same cells, for example calcitonin and katacalcin ${ }^{20}$ glucagon and related peptides. ${ }^{21}$

In this study we have used three antisera (PSN, GL7 and GL9) raised against peptide fragments present in the C-terminal region of the human progastrin molecule. All three antisera detected gastrin-containing cells in human adult and foetal gastric antrum and duodenum, as well as in antral G-cell hyperplasia and pancreatic islet cell tumours producing gastrin (and associated with the ZollingerEllison syndrome). In the normal G-cells, PSN immunoreactivity was localized predominantly to the perinuclear region which would be consistent with the intracytoplasmic site of the Golgi complex. At the ultrastructural level, no peptide immunoreactivity was observed in association with the Golgi apparatus, but this may be the result of epitope masking by unknown factors, rather than reflecting a real absence of the PSN-containing antigen. 

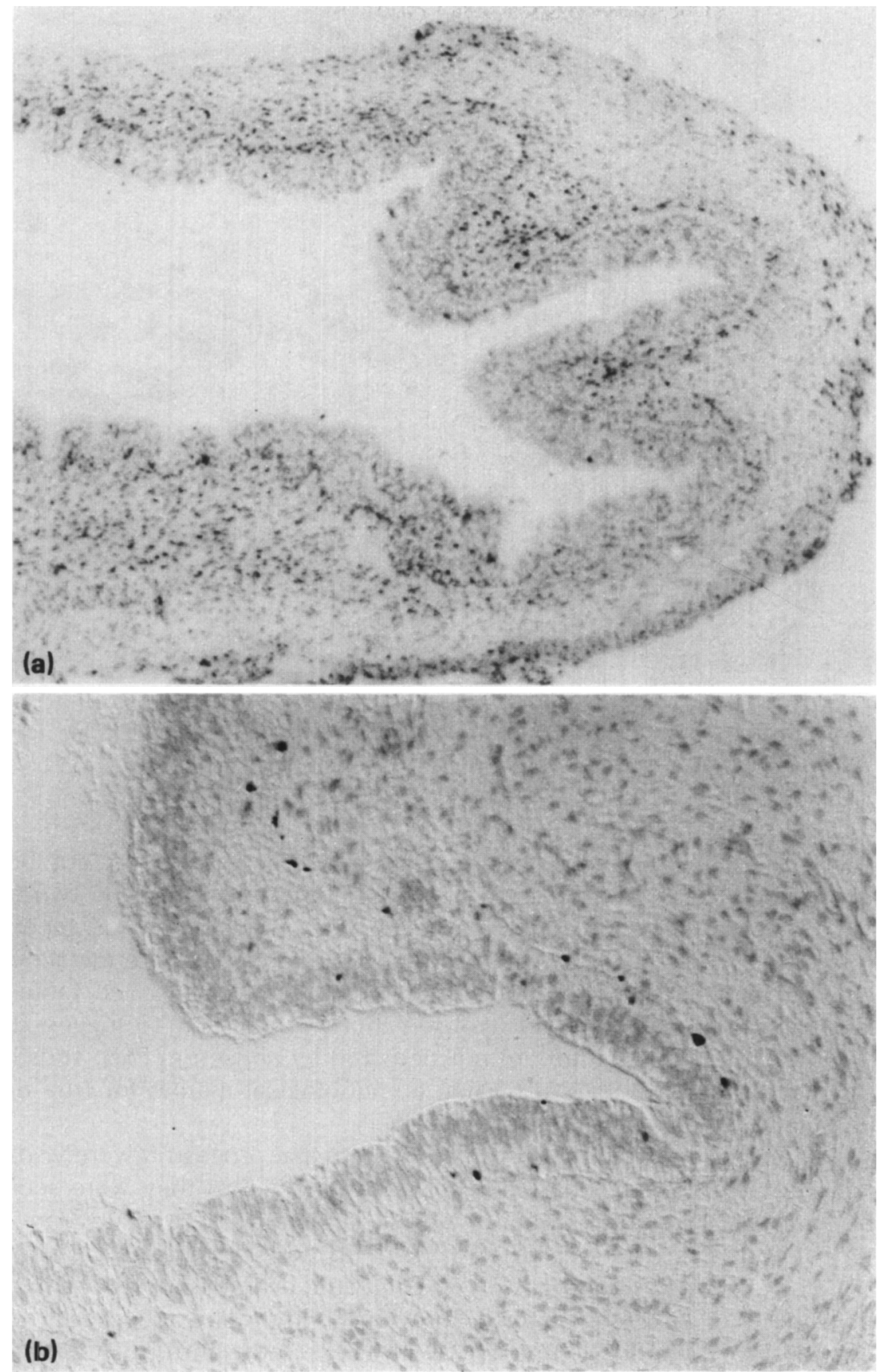

Fig. 7. (a) Haematoxylin and eosin stained section of human foetal stomach of 11 weeks' gestation. Magnification $\times 20$. (b) Gastric mucusa from a human foetus at 11 weeks' gestation containing scattered PSN-immunoreactive cells. Magnification $\times 300$ (with Nomarski optics). 


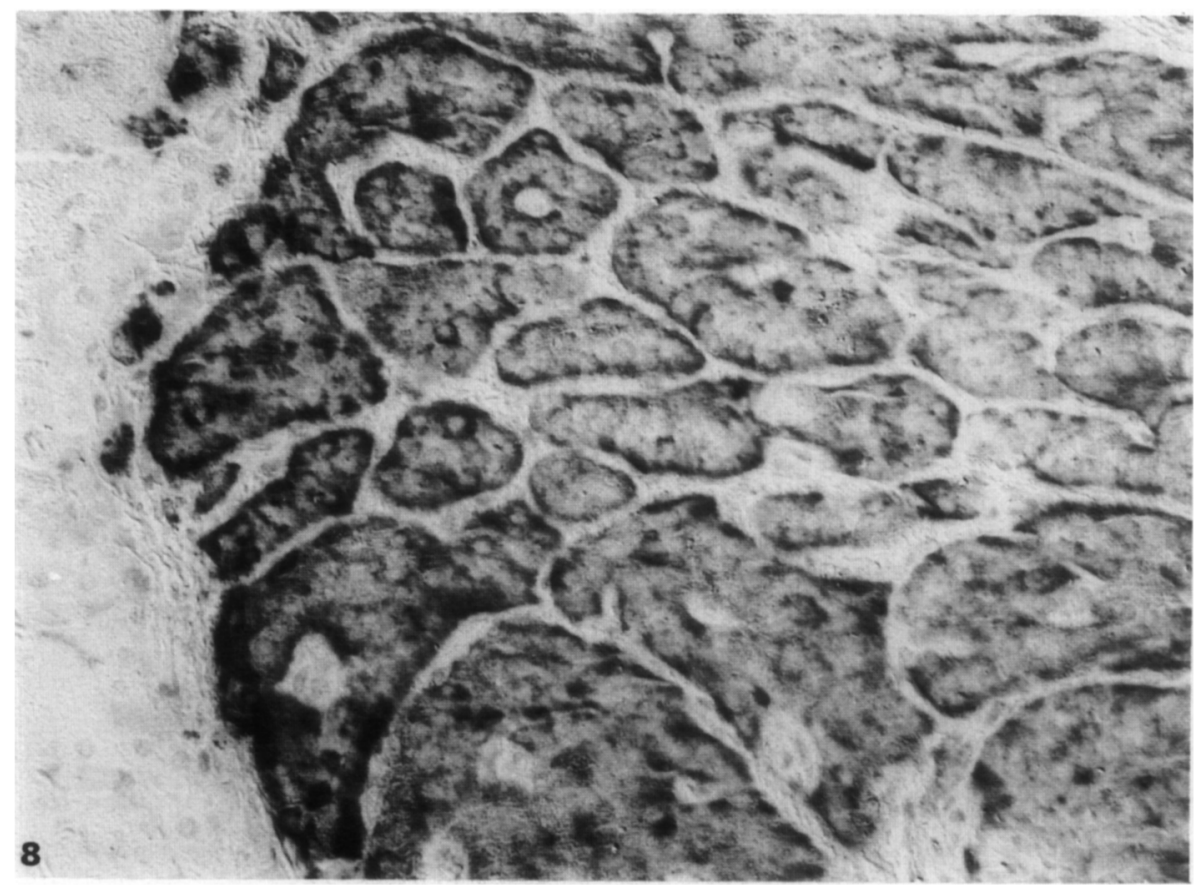

Fig. 8. PSN immunoreactivity in an islet cell tumour from a patient with gastrinoma syndrome. Magnification $\times 150$ (with Nomarski optics).

Gastrin has a C-terminal octapeptide homology with another gut hormone, cholecystokinin (CCK), and because of this structural similarity the two peptides have often been difficult to differentiate by immunocytochemical techniques. ${ }^{22}$ Although the C-flanking peptide of gastrin has a tetrapeptide $\mathrm{N}$-terminal homology with the C-terminal flanking peptide of rat procholecystokinin (see Table 1), light microscopical immunocytochemical observations would seem to suggest that CCK cells present in the duodenum are not detected by antiserum PSN. Thus it would appear that antiserum PSN is a reliable immunological marker for true duodenal gastrin cells at the light microscopical level.

Immunoreactivities for both gastrin and C-terminal progastrin were visualized in cells of the foetal human duodenum some weeks before they were seen in the gastric mucosa. The observation of G-cells appearing first in duodenum is in agreement with the results of other workers on both developing rat and human gut. ${ }^{23-27}$ However, in this study gastrin was detected by immunocytochemistry at an earlier stage than has been reported previously. Immunoreactive cells were first seen at 8 weeks in the duodenum and at 11 weeks in the antrum, in contrast to 10 and 14 weeks, respectively, reported previously. ${ }^{23,27}$ Although these results suggest

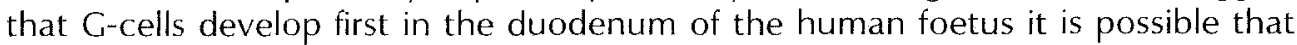
there are G-cells in the antrum also at the 8-weeks stage but containing too little peptide to be immunostained. Certainly it has been shown in foetuses of 10 weeks and above that the gastrin content of the duodenum, as measured by radioimmunoassay, is up to 30 times that of the antrum. ${ }^{26}$ 
The finding that, between 20 and 28 weeks of foetal life, relatively more cells show immunoreactivity for $\mathrm{G}-17$ rather than antiserum PSN is interesting and suggest that progastrin may not be cleaved fully in developing cells. This may also be the case for the gastrin-producing tumours where at the electron microscopical level, no convincing reactivity with antiserum PSN was observed in neoplastic G-cells, which was in striking contrast to the intense labelling associated with antral G-cell secretory granules. These results may be compared with those recently reported by Pauwels et al. ${ }^{28}$ who performed a radioimmunoassay and chromatographic study using an antiserum recognizing the C-terminus of PSN on human gut and gastrinproducing tumour extracts. They concluded that progastrin may not be processed fully into smaller peptides in the tumour cells. Our findings thus provide circumstantial support for the contention that progastrin does not undergo differential posttransitional processing in transformed and perhaps also developing G-cells.

The reasons why progastrin is not cleaved fully to $\mathrm{N}$-terminally extended gastrin and free PSN peptides in neoplastic and developing cells have not been elucidated. It may be that there is abnormal production, relatively low levels or suppression by some means, of the enzyme responsible for gastrin-PSN cleavage. Abnormally high levels of progastrin production, coupled with low enzyme concentrations could also be conceived. Moreover, a recent report ${ }^{29}$ has raised the possibility that human progastrin may exist in two molecular forms, one phosphorylated. If progastrin cleavage is dependent upon one or other molecular form being present this could possibly account for the variability in immunostaining intensity. Thus our study indicates that antisera specific for the C-flanking peptide of progastrin are useful in distinguishing G-cells of the duodenum and for revealing variability in posttranslational processing of progastrin, as seen in developing, hyperplastic and neoplastic G-cells.

\section{ACKNOWLEDGEMENTS}

The authors thank Mr Robert Hennessy for technical assistance and Miss Sandra Lock for typing the manuscript.

\section{REFERENCES}

1. Steiner, D. G., Duguid, J.R., Patzelt, C. et al. (1979). New aspects of insulin biosynthesis. In Proinsulin, Insulin, C-Peptide. (Baba S., Kaneko, T. \& Yanaihara, N., eds) pp. 9-19. Excerpta Medica: Amsterdam.

2. Martinez, J. \& Potier, P. (1986). Peptide hormones as prohormones. Trends in Pharmacological Sciences 7, 139-381.

3. Bell, G. I., Sanchez-Pescador, R., Laybourn, P. J. \& Najarian, R. C. (1983a). Exon duplication and divergence in the human preproglucagon gene. Nature 304, 368-71.

4. Bell, G. I., Santerre, R. F. \& Mullenbach, G.T. (1983b). Hamster preproglucagon contains the sequence of glucagon and two related peptides. Nature $\mathbf{3 0 2}, 716-18$.

5. Lopez, L. C., Frazier, M. L., Su, C.-J., Kumar, A. \& Saunders, G. F. (1983). Mammalian pancreatic preproglucagon contains three glucagon-related peptides. Proceedings of the National Academy of Science, USA 80,5485-9.

6. Solcia, E., Vassallo, G., Capella, C. \& Sampietro, R. (1967). Endocrine cells in the antro-pyloric mucosa of the stomach. Zeitschrift Zellforschung Mikvoskopisch Anatomische 81, 474-86. 
7. Forssmann, W. G., Orci, L., Pictet, R. \& Rouiller, C. (1967). Zur Ultrastruktur der Endokrinen Zellen im Epithel des Magendarmtraktes der Ratte. Acta Anatomica (Basel) 68, 605-6.

8. Hakanson, R., Alumets, J., Rehfeld, J. F., Ekelund, M. \& Sundler, F. (1982). The life cycle of the gastrin granule. Cell Tissue Research 222, 479-91.

9. Varndell, I. M., Harris, A., Tapia, F. J. et al. (1983). Intracellular topography of immunoreactive gastrin demonstrated using electron immunocytochemistry. Experientia 39, 713-17.

10. Yoo, J. O., Powell, C. T. \& Agarwal, K. L. (1982). Molecular cloning and nucleotide sequence of fulllength CDNA coding for porcine gastrin. Proceedings of the National Academy of Science, USA 79, 1049-2053.

11. Kato, K., Himeno, S., Takahashi, Y., Wakabayashi, T., Tarui, S. \& Matsubara, K. (1983). Molecular cloning of human gastrin precursor cDNA. Gene 26 53-7.

12. Boel, E., Vurst, 1., Norris, F. et al. (1983). Molecular cloning of human gastrin CDNA-Evidence for evaluation of gastrin by gene duplication. Proceedings of the National Academy of Science, USA 80, $2866-9$.

13. Sternberger, L. A. (1979). The unlabelled antibody peroxidase anti-peroxidase (PAP) method. In Immunocytochemistry. (Sternberger, L. A., ed.) pp. 104-69. New York: John Wiley \& Sons.

14. Lane, B.P. \& Europa, D. L. (1965). Differential staining of ultrathin sections of EPON-embedded tissues for light microscopy. Journal of Histochemistry and Cytochemistry 13, 579-82.

15. De Mey, J., Moeremans, M., Geuens, G., Nuydens, R. \& De Brabander, M. (1981). High resolution light and electron microscopic localisation of tubulin with the IGS (immunogold staining) method. Cell Biology International Report 5, 889-99.

16. Varndell, I. M. \& Polak, J. M. (1986). Electron microscopical immunocytochemistry. In Immunocytochemistry: Modern Methods and Applications. (Polak, J. M. \& Van Noorden, S. eds) 2nd edn, pp. 328-49. Bristol: John Wright \& Sons.

17. Bendayan, M. \& Zollinger, M. (1983). Ultrastructural localisation of antigenic sites on osmium-fixed tissues applying the protein A-gold technique. Journal of Histochemistry and Cytochemistry $\mathbf{3 1}$ $101-9$.

18. Sugano, K., Aponte, G.W. \& Yamada, T. (1985). Identification and characterisation of glycineextended post-translational processing intermediates of progastrin in porcine stomach. Journal of Biological Chemistry 260, 11724-9.

19. Amara, S. G., Jonas, V. \& Rosenfeld, M. G. (1982). Alternative RNA processing in calcitonin gene expression generated mRNAs encoding different polypeptide products. Nature 298, $240-4$.

21. Varndell, I.M., Bishop, A.E., Sikri, K.L., Uttenthal, L. O., Bloom, S.R. \& Polak, J.M. (1985). Localisation of glucagon-like peptide (CLP) immunoreactants in human gut and pancreas using light and electron microscopic immunocytochemistry. Journal of Histochemistry and Cytochemistry 33, 1080-6.

22. Buchan, A. M. J., Polak, J. M., Solcia, E. \& Pearse, A. G. E. (1979). Localisation of intestinal gastrin in a distinct endocrine cell type. Nature 277, 138-40.

23. Dubois, P.M., Paulin, C. \& Chayvialle, J. A. (1976). Identification of gastrin-secreting cells and cholecystokinin-secreting cells in the gastrointestinal tract of the human foetus and aduit man. Cell Tissue Research 175, 351-6.

24. Kataoka, K., Miura, J., Takeoka, Y. \& Yanaihara, N. (1985). Immunohistochemical study on the development of gastrin cells in the stomach, duodenum and pancreas of rat. Biomedical Research 6, $41-7$.

25. Larsson, L.-I., Hakanson, R., Sjoberg, N.-O. \& Sundler, F. (1975). Fluorescence histochemistry of the gastrin cell in fetal and adult man. Gastroenterology 68, 1152-9.

26. Larsson, L.-I., Rehfeld, J. F. \& Goltermann, N. (1977). Gastrin in the human foetus. Distribution and molecular forms of gastrin in the antropyloric gland area, duodenum and pancreas. Scandinavian Journal of Gastroenterology 12, 869-72.

27. Track, N. S., Creutzfeldt, C., Litzenberg, J., Neuhoff, C., Arnold, R. \& Creutzfeldt, W. (1979). Appearance of gastrin and somatostatin in the human foetal and stomach, duodenum and pancreas. Digestion 19, 292-306.

28. Pauwels, S., Desmond, H., Dimaline, R. \& Dockray, G. J. (1986). Identification of progastrin in gastrinoma, antrum and duodenum by a novel radioimmunoassay. Journal of Clinical investigations $77,376-81$

29. Varro, A., Desmond, H. P., Dockray, G. J. \& Pauwels, S. (1986). Post-translational processing of progastrin: Possible phosphorylation at the C-terminus. Regulatory Peptides 15, 194. 